\title{
Analisis Financial Distress sebagai Prediktor Delisting PT Berau Coal Energy Tbk
}

\author{
Fajar Hari Setyawan ${ }^{1 *}$, Burhanudin $^{2)}$, Rochmi Widayanti ${ }^{3)}$ \\ ${ }^{123)}$ Fakultas Ekonomi, Program Studi Manajemen, Universitas Islam Batik Surakarta \\ e-mail: rajafriha@gmail.com
}

\begin{abstract}
Abstrak
Riset ini mempunyai tujuan untuk mengetahui kemungkinan kebangkrutan (financial distress) dengan model Altman Z-Score pada PT Berau Coal Energy Tbk yang di delisting dari Bursa Efek Indonesia di tahun 2017. Metode analisis yang dipakai dalam riset ini adalah model Altman ZScore. Hasil riset ini dapat disimpulkan berdasarkan dari menganalisis kemungkinan kebangkrutan (financial distress) menggunakan model Altman Z-Score di tahun 2012-2014 bahwa PT Berau Coal Energy Tbk berada dalam situasi perusahaan yang mengalami kesulitan keuangan, karena jika dilihat dari nilai Z-Score yang masih berada di bawah standart Z-Score yaitu 1,81 dan terdapat nilai rasio yang negatif, maka dapat disimpulkan kondisi kinerja keuangan perusahaan termasuk kategori buruk.
\end{abstract}

Kata Kunci: Financial Distress, Altman Z-Score, Delisting

\section{PENDAHULUAN}

Perusahaan terbuka umumnya lebih mudah untuk mendapatkan sumber alternatif pembiayaan sebagai sarana modal. Dengan adanya modal dapat mempermudah kinerja dan kondisi keuangan perusahaan agar menjadi lebih baik. Apabila kondisi keuangan perusahaan baik maka dapat menjadikan acuan bagi investor dan kreditur dalam menanamkan dananya. Oleh karena itu, diperlukan sebuah analisis dan prediksi tentang kondisi keuangan suatu perusahaan.

Laporan keuangan yang diterbitkan dapat digunakan untuk melihat kondisi keuangan suatu perusahaan. Menurut Helfert, Erich.A (2000) Laporan keuangan digunakan untuk observasi dan penilaian yang berupa sifat, cakupan, dan batasannya sebelum dipakai dalam laporan. Menurut Andriawan dan Salean (2016) diperlukan analisis laporan keuangan guna mendapatkan data yang akurat. Sehingga investor dapat mengambil keputusan yang benar atau layak dalam menanamkan modalnya dan dari laporan keuangan tersebut, dapat dilihat kondisi keuangan suatu perusahaan apakah mengalami kesulitan keuangan yang mengarah pada financial distress. Menurut Bahri dan Widyawati (2015), apabila sebuah perusahaan berada dalam kondisi financial distress, maka pihak manajemen perusahaan harus melalukan tindakan-tindakan alternatif agar keuangan perusahaan tidak masuk dalam kondisi yang lebih berat. Karena jika tidak, perusahaan dapat mengalami kebangkrutan atau di likuidasi.

Bursa Efek Indonesia (BEI) indikator kebangkrutan sebagai salah satu penyebab sebuah perusahaan dikeluarkan atau di delisting. Tahun 2017 Bursa Efek Indonesia mengeluarkan empat emiten, yaitu PT Inovisi Infracom, PT Berau Coal Energy Tbk, PT Permata Prima Sakti Tbk, dan PT 
Citra Maharlika Nusantara Corpora Tbk. Dari ke empat emiten tersebut peneliti tertarik pada PT Berau Coal Energy Tbk. (m.tribunnews.com).

PT Berau Coal Energy Tbk berdiri pada tahun 2005 yang berpusat di kalimantan timur dengan kantor perwakilan di jakarta, yang beroperasi dalam eksplorasi, pengembangan, penambangan, pemasaran, perdagangan dan pengangkutan batubara di Kalimantan. Pada tahun 2010 BRAU masuk pada Bursa Efek Indonesia pada papan utama (www.beraucoalenergy.com).

Tahun 2017 Berau Coal Energy Tbk (BRAU) kini menjadi perusahaan tertutup dan tidak lagi mencatatkan sahamnya di Bursa Efek Indonesia (BEI). Anak usaha perseroan yakni PT Berau Coal menandatangani amandemen Perjanjian Karya Pengusahaan Pertambangan Batubara (PKP2B) dengan Kementerian Energi dan Sumber Daya Mineral pada Selasa (14/11/2017). Penghapusan pencatatan efek PT. Berau Coal Energy Tbk dari Bursa Efek Indonesia berlaku efektif sejak 16 November 2017.

Ditahun 2010 baru tercatat di BEI serta mendapatkan berbagai penghargaan dibidang sosial kemasyarakan dan lingkungan hidup dari Pemerintah Indonesia, tetapi tahun 2017 sudah di delisting dari BEI dikarenakan dari tahun 2015-2017 sudah tidak melaporkan kondisi keuangan perusahaannya. Peneliti tertarik meneliti tentang laporan keuangan dari tahun 2012-2014 pada PT Berau Coal Energy Tbk yang di delisting dari Bursa Efek Indonesia (BEI).

Penelitian Syamsul Hadi dan Atika Anggraeni (2008) menggunakan metode Altman Z-Score dikarenakan model Zmijewski tidak dapat digunakan sebagai prediktor delisting. Tetapi model Springate masih dibawah model Altman dalam prediktor delisting, sehingga dapat disimpulkan model Altman Z-score sebagai prediktor terbaik dibandingkan dengan model Zmijewski dan Springate. Sedangkan penelitian Ilmi dan Ruzikna (2017) menunjukan model Altman Z- score bersifat mudah digunakan dan sudah diterapkan di berbagai negara. Dalam penelitian ini menggunakan model Altman Z-score sebagai prediktor delisting.

\section{METODE PENELITIAN}

Jenis Penelitian yang digunakan adalah deskriptif dengan pendekatan kuantitatif. Menurut Fauzi, Muchamad (2009) penelitian deskiptif digunakan sebagai alat analisis dan menyajikan kebenaran data secara sistematis sehingga lebih mudah dipahami dan dimengerti. Menurut Arikunto (2007) menyatakan penelitian deskriptif sebagai alat analisis untuk mengumpulkan informasi tentang fakta yang terjadi saat penelitian.

Menurut fauzi, Muchamad (2009) metode penelitian dengan pendekatan kuantitatif adalah penelitian dengan metode statiska yang mengarahkan pada data yang berupa angka yang diolah, metode ini dilakukan dengan menganalisis data-data laporan keuangan perusahaan yang kemudian dihitung atau dijumlahkan supaya bisa digunakan untuk memberi batasan dalam mengkategorikan perusahaan sehingga didapat kesimpulan perusahaan berhasil atau tidak. Penelitian ini menafsirkan peristiwa atau suatu keadaan ketika perusahaan sebelum di delisting dari Bursa Efek Indonesia dalam 
bentuk angka dalam bentuk dukungan studi kepustakaan yang memperkuat analisa peneliti dalam mengambil kesimpulan yang berdasarkan standar yang sudah ditentukan, kemudian dipaparkan secara tertulis hasil perhitungan indikator variabel penelitian.

Sumber data yang digunakan dalam penelititan ini adalah data sekunder yaitu data yang didapatkan oleh peneliti secara tidak langsung dari obyek penelitian (Hadi dan Anggraeni, 2008), data yang diperoleh berupa dokumen laporan keuangan PT Berau Coal Energy Tbk yang menjadi acuan standar dalam memprediksi financial distress. Data diperoleh dari situs dan website:

1. Bursa Efek Indonesia (www.idx.co.id)

2. PT Berau Coal Energy Tbk (www.beraucoalenergy.co.id)

Menurut Ningsih (2017) metode yang digunakan untuk menganalisis data berupa laporan keuangan yang kemudian diolah dengan rasio yang terdapat pada model Altman Z-Score. Akan tetapi untuk teknik pengolahan datanya dikumpulkan dari hasil penelitian, dalam penelitian ini model Altman yang merupakan alat analisis model formula untuk memprediksi kebangkrutan, dengan rumus yaitu (Hanafi, 2014):

\section{$Z=1,2 X_{1}+1,4 X_{2}+3,3 X_{3}+0,6 X_{4}+1,0 X_{5}$}

Perusahaan yang diteliti kemudian dikelompokkan menjadi tiga kriteria yaitu perusahaan yang berpotensi bangkrut, perusahaan yang hampir bangkrut, dan perusahaan yang sehat. Untuk penilaian perusahaan yang memiliki nilai $\mathrm{Z}$ lebih dari atau sama dengan 2,99 dikategorikan perusahaan yang sehat, tetapi untuk perusahaan yang mempunyai nilai $\mathrm{Z}$ kurang dari atau sama dengan 1,81 dikategorikan perusahaan yang berpotensial bangkrut. Dan untuk nilai 1,81-2,99 dikategorikan sebagai perusahaan yang berada pada daerah abu-abu.

\section{HASIL DAN PEMBAHASAN}

Berikut hasil perhitungan dengan metode Altman Z-Score disajikan dalam bentuk tabel untuk mempermudah peneliti dalam menilai kondisi kesehatan perusahaan.

\section{Net Working Capital To Total Assets (X1)}

Tabel 1. Perhitungan Modal Kerja (Dalam Ribuan Dolar Amerika Serikat)

\begin{tabular}{|c|c|c|c|}
\hline Tahun & Aktiva Lancar & Kewajiban Lancar & $\begin{array}{c}\text { Modal Kerja } \\
\text { (Aktiva Lancar - Kewajiban Lancar) }\end{array}$ \\
\hline 2012 & 936.525 & 1.123 .826 & -187.301 \\
\hline 2013 & 940.122 & 990.363 & -50.241 \\
\hline 2014 & 1.380 .638 & 933.674 & 446.964 \\
\hline
\end{tabular}

Sumber: Data Olahan, 2018

Modal kerja diperoleh dengan cara aktiva lancar dikurangi dengan kewajiban lancar. Hasil perhitungan pada tahun 2012 adalah sebesar -187.301. Tahun 2013 mengalami kenaikan sebesar 137.060 dari tahun 2012. Dan tahun 2014 mengalami kenaikan lagi sebesar 497.205 dari tahun 2013. 
Tabel 2. Perhitungan Rasio X1 (Dalam Ribuan Dolar Amerika Serikat)

\begin{tabular}{|c|c|c|c|}
\hline Tahun & Modal Kerja & Total Aktiva & $\mathrm{X} 1=\frac{\text { Modal Kerja }}{\text { Totalaktiva }}$ \\
\hline 2012 & -187.301 & 2.148 .128 & $-0,087$ \\
\hline 2013 & -50.241 & 1.952 .973 & $-0,026$ \\
\hline 2014 & 446.964 & 1.876 .653 & 0,238 \\
\hline
\end{tabular}

Sumber: Data Olahan, 2018

Variabel $\mathrm{X}_{1}$ menunjukkan kemampuan perusahaan dalam mengelola modal kerja dari total aktiva. Berdasarkan perhitungan di atas, dapat dilihat rasio working capital to total assets di tahun 2012 adalah sebesar -0,087 dan bila diperbandingkan dengan tahun setelahnya yaitu pada tahun 2013, maka rasio working capital to total assets mengalami kenaikan yang cukup baik meskipun masih minus yaitu dari - 0,087 menjadi -0,026. Pada tahun 2009 modal kerja masih negatif dikarenakan total kewajiban lancar yang lebih tinggi dari total aset lancar. Walaupun negatif tetapi total kewajiban lancar mengalami penurunan $13,4 \%$ dari US\$ 1.123 .826 .000 pada tahun 2012 menjadi US\$ 990.363 di tahun 2013.

Pada tahun 2014 rasio working capital to total assets meningkat menjadi 0.238 , hal ini disebabkan peningkatan total aset lancar yang cukup tinggi yaitu dari US\$940.122.00 pada tahun 2013 menjadi US\$ 1.380 .638 di tahun 2014 sehingga modal kerja menjadi positif kembali. Dari perhitungan di atas pada tahun 2012 sampai 2014 rasio working capital to total assets selalu meningkat, hal ini terjadi karena total aset lancar mengalami kenaikan yang signifikan.

\section{Retained Earning To Total Assets (X2)}

Tabel 3. Perhitungan Rasio X2 (Dalam Ribuan Dolar Amerika Serikat)

\begin{tabular}{cccc}
\hline Tahun & Laba Ditahan & Total Aktiva & $\mathrm{X}_{2} \frac{\text { Labaditahan }}{\text { Total Aktiva }}$ \\
\hline 2012 & 86.509 & 2.148 .128 & 0,040 \\
2013 & 278.010 & 1.952 .973 & 0,142 \\
2014 & 356.294 & 1.876 .653 & 0,189
\end{tabular}

Sumber: Data Olahan, 2018

Variabel $\mathrm{X}_{2}$ menunjukkan kemampuan perusahaan dalam memperoleh laba ditahan dari total aktiva. Berdasarkan perhitungan di atas, pada tahun 2012 tingkat profitabilitas perusahaan yang diukur dari rasio retained earning to total assets adalah sebesar 0.040 dan di tahun 2013 terjadi kenaikan menjadi 0.142 , hal ini disebabkan jumlah dividen yang diumumkan perusahaan lebih rendah daripada tambahan laba ditahan sehingga menyebabkan naiknya saldo laba ditahan dan rasio retained earnings to total assets. Dari perhitungan di atas pada tahun 2014 rasio laba ditahan terhadap total aset meningkat menjadi 0,189 disebabkan kenaikan laba ditahan dari tahun 2013 menuju ke tahun 2014 yaitu dari US\$278.010.000 menjadi US\$ 356.294.000. Walaupun total aktiva menurun, tetapi laba ditahan meningkat seperti yang tampak dari perhitungan diatas. 


\section{Earning Before and Tax To Total Assets (X3)}

Tabel 4. Perhitungan Rasio $X_{3}$ (Dalam Ribuan Dolar Amerika Serikat)

\begin{tabular}{ccccc}
\hline \multirow{2}{*}{ Tahun } & $\begin{array}{c}\text { Laba Sebelum } \\
\text { Bunga dan Pajak }\end{array}$ & Total Aktiva & $\mathrm{X}_{3}=\frac{\text { Laba Sebelum.Bungadan Pajak }}{\text { Total Aktiva }}$ \\
2012 & 180.700 & 2.148 .128 & 0,084 \\
2013 & 167.570 & & 1.952 .973 & 0,085 \\
2014 & 114.910 & & 1.876 .653 & 0,061 \\
\hline Sum & & &
\end{tabular}

Sumber: Data Olahan, 2018

Variabel $\mathrm{X}_{3}$ menunjukkan kemampuan perusahaan dalam menghasilkan laba sebelum bunga dan pajak dari total aktiva. Berdasarkan perhitungan di atas, pada tahun 2012 laba bersih sebelum pajak BRAU mengalami penurunan dari tahun sebelumnya yaitu dari US\$ 199.281.000 pada tahun 2011 menjadi US\$ 49.725.000 pada tahun 2012. Karena pada tahun 2012 terjadi peningkatan penjualan dari tahun sebelumnya yaitu dari US\$ 729.063 .000 pada tahun 2011 menjadi US\$ 770.454 .000 pada tahun 2012. Sehingga menghasilkan rasio earning before and tax to total assets sebesar 0.084 .

Pada tahun 2013 rasio earning before and tax to total assets naik menjadi 0.085 , walaupun penjualan meningkat, laba bersih sebelum bunga dan pajak malah mengalami penurunan sebesar 7\% dari tahun sebelumnya. Hal ini disebabkan pada tahun 2013 terjadi peningkatan biaya produksi sebesar 47,56\% yaitu dari US\$ 75.081.000 tahun 2012 menjadi US\$110.791.000 tahun 2013.

Di tahun 2014 rasio earning before and tax to total assets menurun signifikan menjadi 0.061 , hal ini di karenakan penurunan EBIT atau laba sebelum bunga dan pajak sebesar 45\%, menurunnya EBIT atau laba sebelum bunga dan pajak dikarenakan perseroan membukukan kerugian sebesar US\$ 72.467.000, meningkat 18,2\% dibandingkan kinerja tahun 2013. Hal ini dikarenakan melemahnya harga jual rata-rata batubara sebesar 4\% yaitu dari US\$ 61 per ton pada tahun 2013 menjadi US\$ 55 per ton pada tahun 2014. Meskipun volume penjualan meningkat 2,9\% yaitu dari 23,5 juta ton di tahun 2013 menjadi 24,2 juta ton di tahun 2014.

\section{Market Value of Equity to Book Value of Debt (X4)}

Tabel 5. Perhitungan Rasio X4 (Dalam Ribuan Dolar Amerika Serikat)

\begin{tabular}{cccc}
\hline Tahun & $\begin{array}{c}\text { Nilai Pasar } \\
\text { Ekuitas }\end{array}$ & $\begin{array}{c}\text { Nilai Buku } \\
\text { Hutang }\end{array}$ & X4 $=\frac{\text { Nilai Pasar Ekwitas }}{\text { Nilai Buku Hutang }}$ \\
\hline 2012 & 242.272 & 1.905 .856 & 0,127 \\
2013 & 43.010 & 1.909 .963 & 0,022 \\
2014 & 29.457 & 1.906 .110 & 0,015 \\
\hline
\end{tabular}

Sumber: Data Olahan, 2018

Variabel X4 menunjukkan kemampuan perusahaan dalam hal nilai ekuitasnya untuk memenuhi kewajiban-kewajiban atau total hutang yang dimiliki. Berdasarkan perhitungan di atas, menunjukkan bahwa rasio market value of equity to total debt ratio memiliki nilai pasar positif. 
Artinya, perusahaan mampu untuk memenuhi kewajiban dari total hutang yang dimiliki. Walaupun nilai pasar ekuitas mengalami penurunan yang drastis dari tahun 2012 sampai 2014. Nilai pasar ekuitas tertinggi berada pada tahun 2012 yaitu sebesar US\$ 242.272.000 dan menjadikan rasio market value of equity to total debt ratio paling tinggi dibandingkan tahun tahun 2013 dan 2014. Pada tahun 2013 nilai pasar ekuitas mengalami penurunan drastis yaitu sebesar US\$ 43.010.000 dan pada tahun 2014 mengalami penurunan lagi yaitu sebesar US\$29.457.000 sehingga hasil dari rasio market value of equity to total debt ratio juga ikut menurun. Penurunan rasio market value of equity to total debt ratio disebabkan nilai pasar ekuitas yang diperoleh rendah dari meningkatnya jumlah saldo laba yang belum ditentukan penggunaannya. Dampak penurunan nilai pasar ekuitas Perseroan akan memperburuk kelangsungan usaha perusahaan pada tahun berikutnya.

\section{Sales to Total Assets (X5)}

Tabel 6. Perhitungan Rasio X5 (Dalam Ribuan Dolar Amerika Serikat)

\begin{tabular}{|c|c|c|c|}
\hline Tahun & Penjualan & Total Aset & $\mathrm{X}_{5}=\frac{\text { Penjualan }_{\text {Total Aset }}}{\text { Tot }}$ \\
\hline 2012 & 770.454 & 2.148 .128 & 0,358 \\
\hline 2013 & 1.084 .079 & 1.952 .973 & 0,555 \\
\hline 2014 & 1.038 .686 & 1.876 .653 & 0,553 \\
\hline
\end{tabular}

Sumber: Data Olahan, 2018

Variabel $\mathrm{X}_{5}$ menunjukkan tingkat efisiensi penggunaan keseluruhan aktiva perusahaan dalam menghasilkan volume penjualan tertentu. Berdasarkan perhitungan di atas, variabel $\mathrm{X}_{5}$ pada tahun 2012 perusahaan memiliki angka rasio sales to total assets yang paling rendah dibandingkan dengan tahun 2013 dan 2014, pada tahun 2012 perusahaan menghasilkan penjualan yang paling rendah dibandingkan dengan tahun lain dari periode penelitian dan aset yang ada pada tahun 2012 juga merupakan yang paling banyak bila dibandingkan dengan tahun lainnya, hal ini menunjukkan perusahaan tidak mampu memanfaatkan asetnya dengan efesien.

Bila kita perbandingkan tahun 2012 dan 2013, penjualan 2013 mengalami kenaikan dan total aset perusahaan pada tahun 2013 mengalami penurunan. kenaikan tingkat penjualan di tahun 2013 disebabkan harga batu bara yang mengalami penurunan pada tahun 2013 sehingga menghasilkan pendapatan yang lebih tinggi. Total volume penjualan batubara meningkat dari 21,1 juta ton pada tahun 2012 menjadi sebanyak 23,5 juta ton pada tahun 2013. Kesimpulannya dengan nilai aset US\$1 perusahaan dapat menghasilkan penjualan senilai US\$ 0,358 pada tahun 2012 sedangkan pada tahun 2013 perusahaan dapat menghasilkan penjualan senilai US\$ 0,555.

Di tahun 2014 penjualan menurun dari tahun sebelumnya padahal volume penjualan batubara meningkat menjadi 24,2 juta ton. Tetapi harga jual batubara melemah $4 \%$ menjadi US\$ 55 per ton dibandingkan tahun sebelumnya yaitu US\$ 61 per ton. Jadi, manajemen perusahaan harus lebih efisien pada tahun 2014 karena dengan nilai aset US\$1 menghasilkan nilai penjualan yang lebih kecil dari tahun sebelumnya yaitu sebesar US\$ 0,553. 


\section{Hasil Perhitungan Analisis Model Z-Score}

Tabel 7. Data Perhitungan Altman Z-Sore

\begin{tabular}{ccccccccc}
\hline Tahun & Perusahaan & $\mathrm{X}_{1}$ & $\mathrm{X}_{2}$ & $\mathrm{X}_{3}$ & $\mathrm{X}_{4}$ & $\mathrm{X} 5$ & Z-Sore & Kategori \\
\hline 2012 & BRAU & $-0,087$ & 0,040 & 0,084 & 0,127 & 0,358 & 0,663 & Bangkrut \\
2013 & BRAU & $-0,026$ & 0,142 & 0,085 & 0,022 & 0,555 & 1,0163 & Bangkrut \\
2014 & BRAU & 0,238 & 0,189 & 0,061 & 0,015 & 0,553 & 1,3135 & Bangkrut \\
\hline
\end{tabular}

Sumber : Data Olahan, 2018

Berdasarkan tabel data perhitungan Altman Z-Sore, prediksi kebangkrutan PT Berau Coal Energy Tbk periode tahun 2012-2014 menunjukkan bahwa terdapat nilai Z-Sore yang cenderung naik tiap tahunnya akan tetapi masih dalam kondisi bangkrut. Nilai Z-Sore tertinggi berada pada tahun 2014 dengan nilai Z-sore sebesar 1,3135 (nilai Z-Score $\leq 1,81$ peusahaan dalam kondisi bangkrut). Nilai Z-Score terendah berada pada tahun 2012 dengan nilai Z-Score sebesar 0,663 (nilai Z-Score $\leq 1,81$ peusahaan dalam kondisi bangkrut). Secara keseluruhan, prediksi kebangkrutan PT Berau Coal Energy Tbk periode tahun 2012-2014 menggunakan metode Altman Z-Score menunjukkan bahwa kondisi perusahaan dalam kondisi bangkrut atau mengalami kesulitan keuangan.

PT Berau Coal Energy Tbk yang memiliki nilai Z-Score tertinggi adalah pada tahun 2014 yaitu sebesar 1,3135. Kenaikan nilai Z-Score pada tahun 2014 ini jika diteliti disebabkan karena nilai dari variabel Working Capital To Total Assets (X1) memiliki nilai atau rasio yang paling tinggi yaitu sebesar 0,238 di bandingkan dengan dua tahun sebelumnya dan Variabel Retained Earning To Total Assets (X2) memiliki nilai atau rasio yang paling tinggi dengan tahun 2012 dan 2013 yaitu sebesar 0,189. Sedangkan variabel Earning Before and Tax To Total Assets (X3) dan variabel Sales to Total Asset (X5) sedikit lebih kecil nilai atau rasionya di bandingkan dengan tahun 2012 dan 2013. Namun hal ini tidak mempengaruhi nilai Z-Score nya. Selain itu nilai pasar ekuitas yang di miliki oleh PT Berau Coal Energy Tbk (BRAU) pada tahun 2014 relatife kecil di bandingkan dengan dua tahun sebelumnya yaitu hanya sebesar US\$29.457.000. Jadi dapat ditarik kesimpulan bahwa Working Capital To Total Assets (X1) dan Retained Earning To Total Assets ( $\left.\mathrm{X}_{2}\right)$ mempunyai pengaruh lebih besar dalam menentukan nilai Z-Score di bandingkan dengan variabel lainnya dan naik turunnya laba tidak terlalu mempengaruhi dari nilai Z-Score atau kebangkrutan suatu perusahaan tersebut.

Seperti terlihat pada tabel 7, diketahui bahwa PT Berau Coal Energy Tbk selama tiga tahun berturut-turut sebelum dinyatakan delisting dari Bursa Efek Indonesia termasuk dalam kategori perusahaan bangkrut. Keputusan Bursa Efek Indonesia untuk menghapuskan PT Berau Coal Energy Tbk dari bursa sudah tepat, karena kondisi keuangan perusahaan menunjukkan rugi sebesar US\$ 95.876.000 pada tahun 2012, US\$ 61.262.000 pada tahun 2013, dan US\$72.467.000 pada tahun 2014, serta perusahaan tidak melaporkan kondisi keuangannya selama tiga tahun berturut-turut. Dilihat dari nilai Z-score perusahaan tersebut, dimana nilai dari PT Berau Coal Energy Tbk periode 2012-2014 cenderung berada di bawah 1,81 bahkan ada nilai rasio yang 
bernilai negatif yang mengakibatkan perusahaan berpotensial bangkrut. Penelitian ini mendukung penelitian yang dilakukan oleh Syamsul Hadi dan Atika Anggraeni (2008) Z-Score dapat digunakan untuk memprediksi delisting secara moderat. Besar kecilnya nilai Z-Score juga menunjukkan kemungkinan perusahaan akan delist. Semakin besar nilai Z-Score kemungkinan perusahaan akan delist semakin kecil. Serta penelitian yang dilakukan oleh fitria dkk (2017), kondisi keuangan suatu perusahaan baik jika memiliki nilai Z-Score yang melebihi standart Z-Score yaitu 2,99 serta tidak ada nilai rasio yang bernilai negatif.

\section{KESIMPULAN DAN SARAN}

Berdasarkan hasil riset analisis kemungkinan kebangkrutan (financial distress) menggunakan model Altman Z-Score pada tahun 2012-2014 bahwa PT Berau Coal Energy Tbk berada dalam kategori perusahaan yang bangkrut, karena jika di lihat dari nilai Z-Score yang masih berada di bawah standart Z-Score yaitu 1,81 dan terdapat nilai rasio dengan nilai yang negatif, maka dapat disimpulkan kondisi kinerja keuangan perusahaan termasuk kategori buruk. Saran untuk kesempurnaan penelitian selanjutnya adalah diharapkan hasil riset dapat dipakai sebagai referensi terutama periode jangka waktu lebih panjang dan objek penelitian lebih dari satu yang sebaiknya perusahaan yang terindikasi bangkrut agar hasil lebih akurat.

\section{REFERENSI}

Andriawan., Salean. 2016. Analisis Metode Altman Z- Score sebagai Alat Prediksi Kebangkrutan dan Pengaruhnya terhadap Harga Saham pada Perusahaan Farmasi yang Terdaftar di Bursa Efek Indonesia. Jurnal Ekonomi Akuntansi. Vol. 1 No. 1.

Arikunto, Suharsini. 2007. Manajemen Penelitian. Jakarta: PT Rineka Cipta.

Bahri.,Widyawati. 2015. Analisis Prediksi Kebangkrutan pada Perusahaan yang di Delisting di Bursa Efek Indonesia. Jurnal IImu dan Riset Menejemen. Vol. 4 No. 8.

Fauzi, Muchamad. 2009. Metode Penelitian Kuantitatif. Semarang: Walisongo Pres.

Hanafi, Mahmud M. 2014. Manajemen Keuangan. Yogyakarta: BPFE.

Helfert, Erich A. 2000. Analisis Laporan Keuangan. Jakarta: Erlangga.

Ilmi dan Ruzikna. 2017. Analisis Penggunaan Metode Altman Z-Score dalam Memprediksi Terjadinya Financial Distress pada Perusahaan Minyak Bumi dan Gas (Migas) yang Terdaftar di Bursa Efek Indonesia (BEI) periode 2010- 2014. JOM FISIP. Vol. 4 No. 2.

Juwita, Arimbi. 2009. Prediksi Rasio Keuangan terhadap Kondisi Finacial Distress pada Perusahaan Properti yang Terdaftar di Bursa Efek Indonesia. Skripsi. Universitas Sebelas Maret. Surakarta.

Ningsih. 2017. Analisis Penggunaan Metode Altman dalam Memprediksi Kebangkrutan Perusahaan (Studi Perusahaan Plastik dan Kemasan yang Terdaftar di Bursa Efek Indonesia Periode tahun 2012-2014). JOM FISIP. Vol. 4 No.2.

Platt, H D., Platt, M B. 2002. Predicting Corporate Financial Distress: Reflections on Choise-Based Sample Bias. Journal of Economics and Finance. Hal: 184-197.

Rizal, M. 2017. Analisis Economic Value Added PT Garuda Indonesia (Persero) Tbk. Jurnal Serambi Ekonomi dan Bisnis. 4(1), 53-62.

Springate, G L. 1978 . Predicting The Possibility of Failure in a Canadian Firm . Master of Business Administration Project (Unpublished).

Whitaker, R B. 1999. The Early Stages of Financial Distress. Journal of Economics and Finance. Hal: 123-133. 
Wulandari, Fitria., Burhanudin., Widayanti, Rochmi. 2017. Analisis Prediksi Kebangkrutan Menggunakan Metode Altman (Z-Score) pada Perusahaan Farmasi (Studi Kasus pada Perusahaan yang Terdaftar di Bursa Efek Indonesia Tahun 2011-2015). Benefit Jurnal Manajemen dan Bisnis. Vol. 2 No. 1.

Zmijewski, M E. 1984. Methodologi Issues Related to The Estimation of Financial Distress Prediction Models. Journal of Accounting Research, Hal: 59-82. 